\title{
ROMANTISMOS, REALISMOS E ANTICLERICALISMOS em Amor de perdição (Camilo Castelo Branco)
}

\author{
Romanticisms, realisms and anticlericalisms in \\ Amor de perdição (Camilo Castelo Branco)
}

\author{
Antonio Augusto Nery*
}

\begin{abstract}
RESUMO
O crítico Joel Serrão (1919-2008), em sua obra Portugueses Somos (19--), propôs que os autores do Romantismo português, ao aderirem aos princípios das ideias iluministas, transpareceram em seus textos o desejo de preservar a santidade vislumbrada na "essência" do Cristianismo e, ao mesmo tempo, realizaram a denúncia da contraditória prática clerical ao longo da história portuguesa. Serrão explicita que para os intelectuais desse período, os dirigentes católicos deveriam estar empenhados na concretização da nova concepção de sociedade que se desejava, ou seja, os desígnios e objetivos burgueses. Como em terras portuguesas era justamente o contrário disso o que ocorria, as obras literárias românticas traduziram a insatisfação com a atuação da Instituição Religiosa e de seus representantes na sociedade. Levando em consideração os apontamentos críticos de Joel Serrão, pretendemos analisar em que medida tais proposições são condizentes com a obra de Camilo Castelo Branco (1825-1890). Partindo da leitura de Amor de Perdição (1862), averiguaremos as características do discurso anticlerical, focando especificamente a figuração das personagens religiosas presentes na narrativa. Refletiremos também em que medida esse escrito de Camilo dialoga com os textos de seus contemporâneos, particularmente os autores Realistas da Geração de 70 , no que diz respeito à difusão de um pensamento anticlerical e antirreligioso por intermédio da ficção. Esperamos com essa
\end{abstract}


análise problematizar a ideia comumente difundida de que a passionalidade é a principal tônica da obra camiliana.

Palavras-chave: Camilo Castelo Branco; Amor de perdição; Anticlericalismo.

\begin{abstract}
The critical author Joel Serrão (1919-2008), in his work Portugueses Somos (undated), claimed that the Portuguese romanticist authors transcended the wish to preserve the sanctity that lies in the essence of Christianity by following the principles of Illuminism. At the same time, they denounce the contradictory clerical practice that existed throughout Portuguese history. Serrão explains that, for the intellectuals from this period, the church should be more worried about the establishment a new concept of society based on the bourgeois conceptions and goals. As in Portuguese lands the opposite was practiced, the romantic literary work expressed the dissatisfaction with the church and with the clergy in the society. Analyzing Joel Serrão's critical notes, we will evaluate in which way these statements may apply to Camilo Castelo Branco's work (1825-1890). From the reading of Amor de Perdição (1862), we can see some of the characteristics of the anti-clerical discourse, focusing on the representation of the religious characters from the narrative. We will also analyze the ways in which Castelo Branco's book dialogues with the production of writers contemporary to him, especially the realistic authors from the 70'sgeneration, in their diffusion of the anti-clerical and anti-religious ideas through fiction. With this analysis we expect to problematize the common idea that the passion is the most important tone of Castelo Branco's work.
\end{abstract}

Keywords: Camilo Castelo Branco, Amor de Perdição, Anticlericalism.

Se a discussão acerca de períodos literários e, mais especificamente, acerca de Romantismo e Realismo, como estéticas datadas e com características próprias e imutáveis, está vencida ou ultrapassada no meio acadêmico, o mesmo não podemos dizer com relação aos compêndios e livros didáticos que continuam a ser publicados e consumidos de maneira avultante.

Tal constatação não teria a mínima importância se, ainda hoje, compêndios e livros didáticos não fossem grandes responsáveis em apresentar a Literatura para um público que, talvez, só teria chances de obter informações focadas e mais "aprofundadas" sobre esse tema durante a fase de formação no Ensino Fundamental e, principalmente, no Ensino Médio.

A periodização continua sendo a maneira sistemática que os autores desses manuais elegem para expor os escritores e obras que, para eles, 
foram representativos em determinados períodos históricos, fazendo com que as poucas obras literárias e os autores "eleitos" sirvam simplesmente para corroborar as características do dado período literário, desta ou daquela estética. Sabemos por experiência própria, ou pelos inúmeros relatos de pessoas que nos cercam, o quanto essa escolha metodológica pode privar o aprendiz de conhecer outras facetas e características literárias de autores e obras, ou, não às vezes, simplesmente tolhem o gosto pela literatura e, mais grave, pela leitura.

Quando pensamos especificamente na maneira com que Camilo Castelo Branco (1825-1890) e suas obras ainda hoje são apresentados para os leitores "de primeira viagem", podemos constatar, infelizmente, que estamos diante de um bom exemplo dessa metodologia nada proveitosa relatada acima. Vejamos a maneira como Amor de Perdição (1862) e seu autor são retomados em um dos livros didáticos amplamente utilizados na atualidade em diversas escolas públicas do Brasil:

A vida deste autor romântico parece o enredo folhetinesco de suas novelas passionais, não faltando nem os lances pitorescos e mesmo ridículos, nem os lances dramáticos, nem o final trágico [...] Amor de perdição é considerado o romance passional modelar do Ultrarromantismo. Camilo escreveu-o em apenas 15 dias, quando estava preso na cadeia da Relação do Porto por causa do complicado caso amoroso com Ana Plácido. Baseado num caso verídico - a vida de um tio que, no começo do século, estivera preso na cadeia da Relação -, o livro reflete o estado de espírito do autor e possui evidentes elementos autobiográficos (AMARAL et al., 2010, p. 38).

O trecho é retirado do livro Novas Palavras, volume 2, um dos integrantes da coleção homônima, publicada pela Editora FTD. Esse volume possui bons exemplos do padrão clássico com que os livros didáticos apresentam autores e obras. No caso particular do Romantismo em Portugal e de Camilo, propõem o contexto histórico da Estética Romântica; em seguida o que denominam de três fases do Romantismo em Portugal; expõem Camilo como pertencente à $2^{\text {a }}$ fase do Romantismo português, entendida como "Ultrarromântica", sem mencionar minuciosamente as novelas satíricas de costumes produzidas pelo escritor; elencam quais seriam as características do Ultrarromantismo em Portugal, entre as quais: os excessos do subjetivismo e do emocionalismo românticos, o pessimismo, o irracionalismo e o escapismo; e, por fim, propõem a obra camiliana, especialmente Amor de perdição, como principal exemplo ultrarromântico.

Além disso, o trecho citado também deixa clara outra prática comum a esses materiais didáticos quando partem para a análise da obra de Camilo, 
via de regra, seguem a premissa de conectar como algo inseparável vida e obra, muito provavelmente inspirados em leituras críticas pautadas em biografismos, à la Alexandre Cabral (1917-1996) e Jacinto do Prado Coelho (1920-1984)" que por muitos anos vigorou na crítica literária camiliana e que deixou de prever inúmeras características importantes da produção do escritor, como bem problematizou Paulo Franchetti no artigo crítico "A novela camiliana" (2007) ${ }^{2}$.

No tocante a Amor de perdição, os materiais assumem não somente a história de Simão e Teresa como sendo reflexo da história de Camilo e de sua amada Ana Plácido, como também assumem as confissões do narrador como sendo verídicas, simples extensão da realidade, negando as especificidades ficcionais do romance, e crendo, portanto, que a história teria mesmo sido baseada "veridicamente" nos relatos de um tio de Camilo, preso na cadeia da Relação do Porto, conforme o narrador da ficção menciona.

Considerando que as coleções de livros didáticos são escolhidas por determinação do Ministério da Educação a cada três anos, e que a última escolha foi feita em 2010, ao menos até 2013 continuaremos a ter Camilo sendo (re)conhecido nas escolas públicas do Brasil, se depender da coleção de livros mencionada, a partir preponderantemente do estereótipo da passionalidade, em total contramão do que vem sendo discutido por inúmeras leituras críticas atuais, como as apresentadas por vários pesquisadores no Colóquio "O tempo de Camilo", evento acadêmico realizado de 11 a 13 de dezembro de 2012, na Universidade Federal do Paraná3.

Dessa forma, refletir sobre maneiras e métodos de se questionar a periodização com características demarcadas e inquestionáveis pode e necessita fazer parte das discussões acadêmicas, ainda mais se considerarmos que é deste ambiente que partem os futuros professores de língua e literatura que se depararão com tais compêndios e materiais didáticos, obrigados muitas vezes a utilizá-los sem questionamentos, ou até mesmo conhecimento, dos problemas que tal escolha metodológica pode ocasionar no ensino da Literatura.

Especificamente com relação à obra camiliana, proponho como elemento problematizador da já clássica discussão do lugar ocupado pela totalidade da obra de Camilo na estética romântica, a maneira como o escritor constrói e veicula a crítica anticlerical e, por conseguinte, a crítica social, em seus textos.

1 Refiro-me respectivamente a CABRAL, Alexandre. As novelas de Camilo. Lisboa: Portugália, 1961 e COELHO, Jacinto do Prado. Introdução ao Estudo da Novela Camiliana. Coimbra: Atlântica, 1946.

2 FRANCHETTI, Paulo. A novela camiliana. Estudos de literatura portuguesa e brasileira. São Paulo: Ateliê Editorial, 2007, p. 87-100.

3 Disponível em: <http://coloquiotempodecamilo.blogspot.com.br/>. Acesso em: 03/03/2013. 
Sabemos que o anticlericalismo é tema presente na Literatura Portuguesa desde as Cantigas de Escárnio e Maldizer, e os autores do século XIX, com todas as agitações políticas, culturais e de várias outras ordens que tomavam Portugal, não passaram incólumes a essa tradição, uma vez que a Igreja fazia parte da grande estrutura social que precisava ser questionada/modificada. O crítico Joel Serrão (1919-2008), em sua obra Portugueses Somos (19--), propôs que os autores do Romantismo português, ao aderirem aos princípios das ideias iluministas, transpareceram em seus textos o desejo de preservar a santidade vislumbrada na "essência" do Cristianismo e, concomitantemente, realizaram a denúncia da contraditória prática clerical ao longo da história portuguesa. Serrão explicita que para os intelectuais desse período, os dirigentes católicos deveriam estar empenhados na concretização da nova concepção de sociedade que se desejava, ou seja, os desígnios e objetivos burgueses. Como em terras portuguesas era justamente o contrário disso o que ocorria, as obras literárias românticas traduziram a insatisfação com a atuação da Instituição Religiosa e de seus representantes na sociedade.

Contudo, talvez pelo fato de ter sido a Geração de $70^{4}$ e suas propostas realistas, que tenham decretado de maneira direta e eloquente que a Igreja Católica, e tudo o mais que era correlato a ela, seriam uma das três causas da decadência que o país vivenciava no contexto do século XIX ${ }^{5}$, fez com os escritores que não fizeram parte da plêiade de 70 , caso de Camilo, tivessem suas obras pouco analisadas a partir de tal aspecto, merecendo, a meu ver, uma investigação mais aprofundada nesse sentido.

De antemão, o que eu gostaria de propor é que elementos concernentes à crítica anticlerical poderiam ser tidos como questionadores de demarcações frequentes de algumas obras de Camilo Castelo Branco como tendo unicamente cariz passional/ultrarromântico, da maneira que as leituras "didáticas" ainda insistem em veicular, resumindo a economia de algumas obras apenas no interesse em demonstrar que todo e qualquer acontecimento narrado não tem outro objetivo se não o de plenificar as agruras que

4 A Geração de 70 foi formada por um grupo de jovens intelectuais oriundos da Universidade de Coimbra, entre os quais Antero de Quental (1842-1891), Eça de Queirós (1845-1900), Oliveira Martins (1845-1894) e Ramalho Ortigão (1836-1915), que desejavam, a partir da arte (a literatura principalmente) e da cultura, desenvolver a renovação e a desmistificação de tudo o que era considerado ultrapassado e que, segundo eles, atravancava o desenvolvimento de Portugal. Os participantes da Geração de 70 são considerados tradicionalmente como os introdutores e divulgadores da estética Realista no país.

5 Refiro-me à conferência "Causas da Decadência dos Povos Peninsulares nos últimos três séculos”, de Antero de Quental. Esse texto, apresentado em 27 de maio de 1871, no âmbito das Conferências do Casino Lisbonense, é capital para se compreender os propósitos da Geração de 70 , e, por conseguinte, do pensamento Realista em Portugal. Antero propõe o Catolicismo pós-tridentino, junto com a monarquia absolutista e as conquistas ultramarinas como causadores da decadência moral, econômica e social das nações ibéricas; responsáveis pelo atraso do desenvolvimento da indústria e da ciência na península a partir do século XVII. 
impedem o amor ideal de se concretizar, sendo dada, portanto, por parte de Camilo, pouca importância à crítica social com desejo de transformação da sociedade que recebia suas obras.

Para este trabalho, focarei especificamente a maneira como a crítica anticlerical é difundida em $A m o r$ de perdição $o^{6}$, obra mais lembrada do autor e, conforme já mencionei, tradicionalmente proposta como grande exemplo do Romantismo/Ultrarromantismo em Portugal.

As cenas que focarei passam-se todas no convento de Viseu, onde Teresa, uma das protagonistas da história, foi exilada pelo pai, cujo intuito declarado era o de afastá-la de Simão Botelho, o grande amor da menina.

Entre as motivações que levam Tadeu de Albuquerque a afastar Teresa do convívio social está sobretudo o interesse pessoal de não ter a filha entregue ao filho de seu principal inimigo, Domingos Botelho. Mas, também, vale lembrar, que outro motivo determinante para a decisão foi o de se ver contrariado no projeto de ter Teresa casada com o primo Baltasar Coutinho, nobre e de casta social, que garantiria um futuro promissor à moça e à família. São motivos que remetem à questão, muito presente nos textos camilianos, dos desejos e projetos individuais estarem cerceados pela conveniência de outrem ou, simplesmente, por regras sociais.

Dessa forma, o convento, o mosteiro ou o seminário constituem-se, com frequência na obra de Camilo, como os locais privilegiados que "acolhem" o exilado, ou, explicitamente, que colabora com as questionáveis regras sociais da época que a narração pretende deflagrar.

É o caso do destino de Teresa, primeiramente no convento de Viseu e, posteriormente, no convento de Monchique, no Porto. Já na primeira carta que a menina escreve a seu amado Simão, percebemos o sentido ameaçador com que a personagem compreende o local ao informar, literalmente, que seria "encerrada" em claustro conventual, caso decidisse levar o romance adiante e não aceitasse casar com o primo Baltasar: "Meu pai diz que me vai encerrar num convento por tua causa. Sofrerei tudo por amor de ti" (AP, 1987, p. 29).

Tadeu de Albuquerque tenta inicialmente impelir a filha ao convento por meio de chantagens emocionais, afirmando que estava a "resvalar na sepultura e mais depressa desceria a ela" (AP, 1987, p. 35), caso não fosse atendido. Teresa aparentemente parece aceitar, pois "Prometeu-lhe julgar-se morta para todos os homens, menos para seu pai" (AP, 1987, p. 35), porém, segundo carta enviada em seguida a Simão, vemos que não passavam de "contemporizações", para que o pai a concebesse resignada e obediente.

o convento revela-se, todavia, como grande dissabor para a protagonista, no prenúncio que Tadeu de Albuquerque faz ao notar que defi-

6 Doravante AP nas referências de citações. 
nitivamente não conseguiria concretizar o arranjo do casamento da filha com o sobrinho:

Meu pai... - continuou ela, chorando, com as mãos erguidas mate-me; mas não me force a casar com meu primo! É escusada a violência, porque eu não caso! Tadeu mudou de aspecto, e disse irado: - Hás de casar! - Quero que cases! Quero!... Quando não, amaldiçoada serás para sempre, Teresa! Morrerás num convento! [...] Malditas sejas! Entra nesse quarto, e espera que daí te arranquem para outro, onde não verás um raio de sol (AP, 1987, p. 37, grifo nosso).

A tonalidade trágica com que a morte em um convento se configurava parecia somente não ser menor diante da vergonha que a clausura forçada poderia representar para a sociedade. Mesmo considerando as intenções escusas de Baltasar Coutinho em querer a prima perto de si, temos nas tentativas que ele empreende para dissuadir o tio a não enviar Teresa para Viseu, a expressão desse infortúnio para a família:

Malograda a tentativa do seu amor de emboscada, tornou para a terra o primo de Teresa, dizendo ao velho que ele o livraria do assédio em que Simão Botelho lhe tinha o coração da filha. Não aprovou a reclusão no convento, discorrendo sobre as hipóteses infamantes que a opinião pública inventaria. Aconselhou que a deixasse estar em casa, e esperasse que o filho do corregedor viesse de Coimbra (AP, 1987, p. 37).

As "hipóteses infamantes", entretanto, não foram suficientes para demover os projetos de Tadeu de Albuquerque para a filha, e é assim que temos durante todo o capítulo VII, as descrições de Teresa enclausurada, convivendo com as freiras e as rotinas do convento de Viseu.

Embora a protagonista tenha chegado ao convento preservando certo orgulho romântico de se ver livre das pressões do pai e das investidas do primo, logo no primeiro contato com as monjas, ela percebe com admiração que adentrou em uma microssociedade que tinha regras e maneiras próprias de compreender as relações humanas e que, ao contrário de ser um local moralmente exemplar e de virtudes, tratava-se, na verdade, de um espaço onde os sentimentos humanos mais elementares, como o amor e a liberdade, eram rechaçados. Além disso, vigorava no local uma hierarquia de poder, com títulos e formas de tratamentos próprios da Igreja Católica que, na prática, se constituía somente um prolongamento da estrutura social 
burguesa da época, afeita a títulos nobiliárquicos e formas de tratamento melindrosos, de acordo com o cargo ocupado por este ou aquele:

\begin{abstract}
Abriu-se a portaria do mosteiro. Teresa entrou sem uma lágrima. Beijou a mão de seu pai, que ele não ousou recusar-lhe na presença das freiras. Abraçou suas primas, com semblante de regozijo; e, ao fechar-se a porta, exclamou, com grande espanto das monjas: - Estou mais livre que nunca. A liberdade do coração é tudo. As freiras olharam-se entre si, como se ouvissem na palavra "coração" uma heresia, uma blasfêmia proferida na casa do Senhor. - Que diz a menina?! [...] - Disse eu que me sentia aqui muito bem, minha senhora. - Não diga - minha senhora - atalhou a escrivã. - Como hei de dizer? - Diga: "nossa madre prioresa". - Pois sim, nossa madre prioresa, disse eu que me sentia aqui muito bem. - Mas quem vem para estas casas de Deus não vem para se sentir bem tornou a nossa madre prioresa. - Não?! - disse Teresa com sincera admiração. - Quem para aqui vem, menina, há de mortificar o espírito, e deixar lá fora as paixões mundanas (AP, 1987, p. 58).
\end{abstract}

Parecendo ainda querer aprofundar o desvelamento das relações existentes dentro da Igreja Católica, altamente conectadas com as práticas sociais que são nitidamente questionadas, a narração investe na exposição dos primeiros diálogos que Teresa estabelece com a Madre Prioresa.

A religiosa de imediato propõe que tem dúvidas sobre o tempo de permanência da moça no convento porque não sabia se Tadeu de Albuquerque poderia "querer que a menina professe em ordem rica das bentas ou bernardas" (AP, 1987, p. 58), em uma clara indicação que no momento da escolha desta ou daquela ordem, muito mais que a vocação ou a identificação pessoal do vocacionado, o que imperava era a lógica dos princípios sociais burgueses do abastamento, da riqueza e do renome, além é claro, da obediência a preceitos patriarcais sobrepostos à vontade individual.

Teresa, porém, recusa veementemente a ideia de se tornar freira, expondo para a Madre a disposição de contrariar o pai e a abominação que tal ideia representava para si: "Eu não quero ser freira aqui, nem noutra parte. - A senhora há de ser o que seu pai quiser que seja. - Freira!? A isso não pode ninguém obrigar-me! - recalcitrou Teresa" (AP, 1987, p. 58).

Se levarmos em consideração o teor das respostas e a maneira irônica com que são expostas, somos levados a pensar que a condição "freira" era algo não somente abominado por Teresa naquela situação específica, mas nefando se concebido em qualquer circunstância.

A Madre Prioresa parece concordar com os argumentos de Teresa, porém, talvez motivada pelas contestações, passa a elencar as benesses de 
se viver em um convento. Essas proposições são importantes porque além de serem fundamentais para as desconstruções que serão operadas a partir delas, também traduzem o discurso de aparências sobre a vida em conventos e mosteiros que muito provavelmente era difundido para sociedade e para os "vocacionados" que pensavam em seguir a vida religiosa:

[...] como a menina tem de noviciado um ano, sobra-lhe tempo para se habituar a esta vida, e verá que não há vida mais descansada para o corpo, nem mais saudável para a alma. [...] Todos temos as nossas mortificações e obrigações de coro e de serviços para que nem sempre o espírito está bem disposto. Ora vês aí. Mas, em comparação do que lá vai pelo mundo, o convento é um paraíso. Aqui não há paixões, nem cuidados que tirem o sono, nem a vontade de comer, bendito seja o Senhor! Vivemos umas com as outras como Deus com os anjos. O que uma quer querem todas. Más línguas é coisa que a menina não há de achar aqui, nem intriguistas, nem murmurações de soalheiro (AP, 1987, p. 59).

A explicitação de que as proposições da Madre Prioresa não passavam de falácias acontece praticamente ao mesmo tempo em que a religiosa sai de cena e deixa na presença de Teresa outras duas freiras, a Mestra de Noviças e a Madre Organista.

Aqui a deixo com a senhora madre organista, que é uma pomba, e com a nossa mestra de noviças, que sabe dizer melhor que eu o que é a virtude nestas santas casas. Apenas a prioresa voltou as costas, disse a organista à mestra de noviças: - Que impostora! - E que estúpida! - acudiu a outra. - A menina não se fie nesta trapalhona, e veja se seu pai lhe dá outra companhia enquanto cá estiver, que a prioresa é a maior intriguista do convento. Depois que fez sessenta anos, fala das paixões do mundo como quem as conhece por dentro e por fora. Enquanto foi nova, era a freira que mais escândalos dava na casa; depois de velha era a mais ridícula porque ainda queria amar e ser amada; agora, que está decrépita, anda sempre este mostrengo a fazer missões e a curar indigestões. Teresa, apesar da sua dor, não pôde reprimir uma risada, lembrando-se da vida de Deus com os anjos que as esposas do Senhor ali viviam, no dizer da madre prioresa (AP, 1987, p. 59).

Além do claro confronto que o discurso das religiosas faz à "vida de Deus com os anjos" nos conventos, anunciada pela Madre Prioresa, temos aqui o prolongamento da crítica inicial, agora se voltando não somente ao ambiente de fofocas, mas, sobretudo, às contradições existentes entre os 
discursos difundidos sobre a suposta vida virtuosa de alguns religiosos e a verdadeira postura adotada por esses em seus hábitos cotidianos, em nítida apologia ao fato de que embora houvesse a difusão - e a cobrança aos fiéis - de que se vivia uma vida regrada, casta, compungida, de sacrifícios e martírios, a grande verdade é que, de fato, vivia-se o contrário do que se pregava.

Tal intuito da narrativa se acentua tão logo a Madre Prioresa volta à cena e, na ausência das outras duas religiosas, rapidamente se contradiz e confirma sua desfaçatez ao apressadamente revelar à Teresa que a Madre Organista era libertina e a Mestra das Noviças desvirtuava as vocacionadas, ao invés de orientá-las e aconselhá-las:

Que eu, cá de mim, até ao presente, Deus louvado, não sei o que sejam paixões; mas quem tem cinqüenta e cinco anos de convento, tem muita experiência do que vê penar às outras doidivanas. E, para não ir mais longe, estas duas que daqui saíram têm pagado bem o seu tributo à asneira, Deus me perdoe, se peco. A organista tem já os seus quarenta bons, e ainda vai ao locutório derreter-se em finezas; a outra, apesar de ser mestra de noviças, à falta doutra que quisesse sê-lo, se eu lhe não andasse com o olho em cima, estragava-me as raparigas (AP, 1987, p. 59-60).

Nesta altura da narração fica claro que a fofoca era algo totalmente normal no convento, sendo que a Madre Prioresa nem mais se esforça em esconder que não somente a faz, inadvertidamente, mas incentiva a prática. Percebemos isso quando outra freira, a escrivã, surge no quarto de Teresa, na continuação do trecho citado anteriormente:

Este edificante discurso de caridade foi interrompido pela madre escrivã, que vinha, palitando os dentes, pedir à prelada um copinho de certo vinho estomacal com que todas as noites era brindada. Estava eu a dizer a esta menina as peças que são a organista e a mestra - disse a prioresa. - Oh! são para o que eu lhe prestar! Lá foram ambas para a cela da porteira. A esta hora está a menina a ser cortada por aquelas línguas, que não perdoam a ninguém. Vais tu ver se ouves alguma coisa, minha flor? - disse a prelada. A escrivã, contente da missão, foi imperceptivelmente ao longo dos dormitórios até parar a uma porta, que não vedava o ruído estridente das risadas. - Esta escrivã não é má rapariga. Só tem o defeito de se tomar da pingoleta; depois, não há quem a ature. Tem uma boa tença, mas gasta tudo em vinho, e tem ocasióes de entrar no coro a fazer ss que é mesmo uma desgraça. [...] A mim já ela me assacou um aleive, dizendo que eu, quando saía a ares, não ia só a ares, e andava por lá a fazer o que fazem as outras. 
Forte pouca vergonha! Lá que outra falasse, vá; mas ela, que tem sempre uns namorados pandilhas que bebem com ela na grade, isso lá me custa; mas, enfim, não há ninguém perfeito!... Boa rapariga é ela... se não fosse aquele maldito vício... (AP, 1987, p. 60).

Como se estivéssemos em um campo de batalha discursivo de fofocas, tão logo a Prioresa sai, adentra novamente o quarto de Teresa a escrivã que, ao invés de dar notícias acerca da "missão" a que tinha sido enviada, apressa-se em desferir acusações sobre a Prioresa, a qual "velhíssima como a sé" e grosseira, era também alcoólatra, devassa e ladra: "Ela o vinho não bebe, suga-o; é uma esponja viva. Em quanto à libertinagem, tomara eu tantos mil cruzados como de amantes ela tem tido! (...]) é uma dissipadora dos rendimentos da casa. Eu, que sou escrivã, é que sei o quanto ela rouba" (AP, 1987, p. 61).

A narração, a partir deste ponto até o fim do capítulo, segue apresentando os discursos da Madre Prioresa e da Freira Escrivã que degeneram uma a outra à medida que entram e saem do quarto de Teresa. Entretanto, quando ambas as religiosas encontram-se juntas no local, tratam-se com floreios e apelidos carinhosos, em uma clara demonstração de falsidade e hipocrisia:

A prelada vinha entrando, e a escrivã prosseguiu assim:

- Não há, não há nada mais agradável que a vida do convento quando se tem a fortuna de ter uma prelada como a nossa... Aí! Eras tu, menina? Olha se estivéssemos a falar mal de ti!

- Eu sei que tu nunca falas mal de mim - disse a prelada, piscando o olho a Teresa. - Aí está essa menina que diga o que eu lhe estive a dizer das tuas boas qualidades... [...]

- Então não vais ao coro, Nini? - tornou a prioresa.

- Já agora é tarde... Tu absolves-me da falta, sim?

- Absolvo, absolvo; mas dou-te como penitência beberes um copinho...

- Do estomacal?

- Pudera!

Dionísia cumpriu a penitência, e saiu para, dizia ela, deixar a prelada na sua hora de oração (AP, 1987, p. 62).

Teresa neste ponto do enredo já aparenta estar totalmente desconcertada e estupefata diante das cenas ignóbeis. As difamações e fingimentos são tamanhos que em certo momento o narrador, após relatar o ar de desilusão com que a protagonista recebia cada uma daquelas intrigas, nos relata que por conta de sua condição de "encarcerada" e frente à movimentação 
das freiras no quarto, em certo momento "com as mãos abertas sobre a face, dizia em si: 'um convento, meu Deus! Isto é que é um convento?!'” (AP, 1987, p. 60) e, em outra ocasião, tinha: "a esperança de poder desafogar em lágrimas a sua aflição” (AP, 1987, p. 61) até que, por fim:

Encheu-se o coração de Teresa de amargura e nojo naquelas duas horas de vida conventual. Ignorava ela que o mundo tinha daquilo. Ouvira falar dos mosteiros como de um refúgio da virtude, da inocência e das esperanças imorredoiras. Algumas cartas lera de sua tia, prelada em Monchique, e por elas formara conceito do que devia ser uma santa. Daquelas mesmas dominicanas, em cuja casa estava, ouvira dizer às velhas e devotas fidalgas de Viseu virtudes, maravilhas de caridade, e até milagres. Que desilusão tão triste e, ao mesmo tempo, que ânsia de fugir dali! (AP, 1987, p. 62).

O narrador sugere que os acontecimentos se instituem como grande revelação negativa para a concepção que Teresa - e por que não dizer os (as) leitores (as) - tinha dos conventos e da vida religiosa. Serão diversas as cartas endereçadas a Simão em que a protagonista relata a experiência trágica, porém reveladora, que teve em Viseu: "Não fazes idéia do que é um convento! Se eu pudesse fazer um sacrifício a Deus, teria de procurar uma atmosfera menos viciosa que esta. Creio que em toda parte se pode orar e ser virtuosa, menos neste convento" (AP, 1987, p. 73).

Não continuarei a analisar os trechos do capítulo VII porque, sinceramente, são muitas fofocas e hipocrisias para "pouco artigo". Aliás, o próprio narrador, de maneira irônica, diz que se deu por satisfeito com suas descrições sobre o antro de calúnias e difamações que se queria ilustrar: "Não delongaremos esta amostra do evangélico e exemplar viver do convento onde Tadeu de Albuquerque mandara sua filha a respirar o puríssimo ar dos anjos [...]" (AP, 1987, p. 62).

Na verdade, acredito que as citações já são de fato suficientes para demonstrar o que me interessa: o teor crítico e ferino da crítica anticlerical presente em Amor de Perdição. Em uma leitura apressada, esse discurso crítico pode passar despercebido, constituindo-se apenas mais um dos elementos que envolvem os sofrimentos de Teresa; colaborando supostamente apenas como "acessório" na economia da obra para ilustrar a sociedade pérfida que dificultava a realização plena do foco principal da narrativa: a concretização do amor puro, inocente e ideal de Simão e Teresa. Contudo, me parece que apostar em uma leitura nesses parâmetros é diminuir consideravelmente os sentidos interpretativos possibilitados por essas cenas e, claro, pela totalidade da obra. Estamos diante de todo um capítulo do texto, aberto, me parece, não somente para relatar a vivência de Teresa em Viseu, mas, 
sobretudo, focar de forma crítica e específica um aspecto daquela sociedade do Oitocentos que se queria, no mínimo, desvelar e criticar.

No intuito de problematizar a mera tonalidade romântica "trágica-passional" de Amor de perdição, "pincei" neste trabalho alguns exemplos da crítica social realizada por intermédio da crítica anticlerical, mas eu poderia citar as inúmeras digressões operadas pelo narrador para relatar episódios que, embora conectados com o foco principal da narrativa, constituem-se praticamente histórias ou relatos paralelos, os quais, em minha opinião, estão imbuídos com claras apologias críticas à sociedade ${ }^{7}$.

No que diz respeito ao anticlericalismo e levando em consideração somente os discursos presentes em Amor de perdição, sem utilizar outras obras camilianas nas quais a temática religiosa é foco central de interesse, como A bruxa de monte Córdova (1867) e O santo da montanha (1866), por exemplo, temos aqui um Camilo muito próximo da Geração de 70, o movimento que supostamente deflagrou a estética Realista em Portugal.

Poderíamos, inclusive, arriscar a dizer, que quando Antero de Quental explicitou que a Igreja Católica e a atuação de seus representantes no país foram responsáveis pela decadência de Portugal depois do século XVII, somente estava sistematizando a compreensão que os leitores das obras de Camilo já podiam perceber na postura de tantas freiras e padres que figuravam nas ficções que liam.

Apenas a título de ilustração, quando focamos na maneira como o narrador camiliano descreve a aversão das freiras aos sentimentos humanos mais elementares, qualquer semelhança com relação à Igreja Católica e à postura de alguns religiosos explicitados por Eça de Queirós em $O$ crime do Padre Amaro (1871) e A relíquia (1887) não é mera coincidência, aliás, a descrição camiliana poderia ser sintetizada no modo como o narrador queirosiano descreve, por exemplo, Dona Patrocínio das Neves, uma das personagens secundárias de $A$ relíquia:

[...] para a tia Patrocínio todas as ações humanas, passadas por fora dos portais das igrejas, consistiam em andar atrás de calças ou andar atrás de saias: - e ambos estes doces impulsos naturais lhe eram igualmente odiosos [...] a titi entranhara-se, pouco a pouco dum rancor invejoso e amargo a todas as fortunas e a toda graça do

7 Entres essas digressões, cito também como um dos exemplos, todo o capítulo XVI, aberto, segundo o narrador, para esclarecer ao leitor o destino do irmão de Simão, Manuel Botelho, e da açoriana adúltera com quem este fugira logo no início da história. Todavia, a narração em todo esse capítulo parece querer apontar unicamente para questões relacionadas à maneira como o adultério era compreendido naquele contexto, questões que nada tem a ver com as mazelas enfrentadas por Simão e Teresa para viverem seu grande amor. O narrador traz, inclusive, em nota de rodapé, um relato datado de "Hoje, 28 de setembro de 1861", no qual um advogado requer os bens levados pela esposa adúltera, enfatizando que o requerente desejava reaver somente os bens e não a mulher que o traiu. 
amor humano. E não lhe bastava reprovar o amor como coisa profana: a Sr. ${ }^{a}$ D. Patrocínio das Neves fazia uma carantonha, e varria-o como coisa suja. Um moço grave, amando seriamente, era para si "uma porcaria!". Quando sabia de uma senhora que tivera um filho, cuspia para o lado e rosnava - "que nojo". E quase achava a Natureza obscena por ter criado dois sexos. Todas as recreações moças: um passeio gentil com senhoras, em burrinhos; um botão de rosa orvalhado oferecido na ponta dos dedos; uma decorosa contradança em jucundo dia de Páscoa; outras alegrias, ainda mais cândidas, pareciam à titi perversas, cheias de sujidades, e chamava relaxações [...] Mas era ela própria que sem cessar aludia a desvarios e pecados da carne - para os vituperar, com ódio (QUEIRós, 1976, p. 34).

Assim, com relação especificamente à crítica anticlerical, pode-se inferir que estamos diante, tanto na obra de Eça quanto na obra de Camilo, de uma representação mimética da postura com que os religiosos e religiosas eram concebidos no contexto do Oitocentos, quase sem nenhuma diferença na maneira com que os autores ilustram e, por meio da ironia e do sarcasmo, questionam essas posturas.

Nesse sentido, um aspecto muito interessante perceptível em Amor de perdição com relação ao anticlericalismo, e que está totalmente em sintonia com a Geração de 70, especialmente com Eça de Queirós, é a aparente necessidade em apontar uma face positiva da vida religiosa em meio aos inúmeros aspectos negativos que estão sendo apresentados e criticados, quase como uma necessidade de não generalização das posturas deploráveis ou de se propor que "nem tudo está perdido".

Cito como exemplo, remetendo-me a uma das obras de Eça, do único padre moralmente exemplar de $O$ crime do Padre Amaro, o abade Ferrão. Mesmo afeito à caça, prática questionável e impensável para alguém pertencente à ordem franciscana, Ferrão possuía inúmeras virtudes e era um ótimo clérigo se comparado aos hipócritas e repreensíveis Padre Amaro, Cónego Dias, Padre Brito e Padre Natário.

Contraponto parecido pode-se também constatar em Amor de Perdição, pois, se na maioria das cenas em que figuram religiosos, ou em que há menções a eles e elas, percebemos a tentativa do narrador em demonstrar que as atitudes dos clérigos e freiras quase nunca eram bem intencionadas, demonstrando sempre haver uma intenção escusa orientando as atitudes "santas" e "honestas", temos também a aparente preocupação da narrativa em apresentar o que seria um comportamento religioso exemplar.

Percebe-se isso em certas condescendências do narrador nas descrições das religiosas e das rotinas do Convento de Monchique, no Porto, local para onde Teresa é levada logo após a estada no Convento de Viseu. Com o intuito de afastar a filha ainda mais das influências de Simão Botelho, Tadeu 
de Albuquerque resolve enviá-la para o Porto e recorre a uma prima que é abadessa de Monchique. A freira é descrita desde o princípio como alguém prudente e virtuosa que, inclusive, tenta dissuadir a ida involuntária de Teresa para o claustro enviando-lhe uma carta. Entretanto, a missiva que continha as reflexões é desviada da destinatária e reinterpretada por Albuquerque, o qual, provavelmente, tinha receio dos efeitos que as palavras da prima religiosa pudessem causar na já contrariada Teresa:

A prelada de Monchique, religiosa de sumas virtudes, cuidando que a filha de seu primo muito de sua devoção e amor a Deus se recolhia ao mosteiro, preparou-lhe casa, e congratulou-se com a sobrinha de tão piedosa resolução. A carta congratulatória não a recebeu Teresa, porque viera à mão de seu pai. Continha ela reflexões tendentes a desvanecê-la do propósito, se algum desgosto passageiro a impedia à imprudência de procurar um refúgio onde as paixões se exacerbavam mais. Tomadas todas as precauções, Tadeu de Albuquerque fez avisar sua filha de que sua tia de Monchique a queria ter em sua companhia algum tempo, e que a jornada se faria na madrugada do dia seguinte. (...) Foi Teresa recebida com brandura por sua tia, posto que as recomendações de Tadeu de Albuquerque eram clausuras rigorosa e absoluta privação de meios de escrever a quem quer que fosse (AP, 1987, p. 73, 99).

Ilustrada como uma freira que "ciliciava o corpo com as rosetas, e o coração com as provações tormentosas de quarenta anos" (AP, 1987, p. 99), a abadessa e as outras religiosas de Monchique são apresentadas como "boas almas" (AP, 1987, p. 132) que ajudavam Teresa na contínua troca de cartas com Simão, além de fazerem "piedosos artifícios" (AP. 1987, p. 132) para tentarem amparar e dar esperanças à jovem desiludida.

Ainda com relação às proximidades com as obras realistas no que diz respeito à crítica anticlerical, percebo também em Amor de perdição remissões a elementos da religiosidade popular e, por intermédio disso, à maneira como a religião estava conectada aos mecanismos de favores presentes na sociedade. Ao relatar os motivos pelos quais ajudava Simão, o ferrador João da Cruz explica que tinha uma dívida de gratidão com o pai do rapaz, o Corregedor Domingos Botelho, e os conseguiu invocando a devoção do Corregedor à Nossa Senhora das Dores:

Prenderam-me, e fui para Viseu e já lá estava há três anos, no ano que o paizinho de vossa senhoria veio corregedor. Andava muita gente a trabalhar contra mim, e todos me diziam que eu ia pernear na forca. Estava lá na enxovia comigo um preso a cumprir sentença, e disse-me ele que o senhor corregedor tinha muita devoção com 
as sete dores de Nossa Senhora. Uma vez que ele ia passando com a família para a missa, disse-lhe eu: - "Senhor corregedor, peço a vossa senhoria, pelas sete dores de Maria Santíssima, que me mande ir à sua presença para eu explicar a minha culpa a vossa senhoria". O paizinho de vossa senhoria chamou o meirinho-geral, e mandou tomar o meu nome. Ao outro dia fui chamado ao senhor corregedor, e contei-lhe tudo, mostrando-lhe ainda as cicatrizes do braço. Seu pai ouviu-me, e disse-me: - "Vai-te embora, que eu farei o que puder". o caso é, meu fidalgo, que eu saí absolvido, quando muita gente dizia que eu havia de ser enforcado à minha porta. Faz favor de me dizer se eu não devo andar com a cara onde o seu paizinho põe os pés?! (AP, 1987, p. 44).

Fica claro que o pai de Simão agiu em favor do ferrador por conta de sua devoção à Nossa Senhora ou por simples piedade, sem ao menos considerar o delito cometido pelo prisioneiro, qual seja, o assassinato de um almocreve. A crítica é dupla, aponta para o fato de um homem da lei agir sem qualquer escrúpulo ético-profissional, guiado unicamente por suas crenças, bem como deflagra a prática do mecanismo de favor ao enfatizar que o ferreiro detinha uma noção de débito e subserviência ao Corregedor, não obstante as críticas que Simão Botelho dirigia ao pai.

Se diferentemente da Geração de 70 não encontramos na obra de Camilo apologias diretas a uma antirreligiosidade ou ateísmo, bem como questionamentos mais ferrenhos direcionados à crença, podemos pressupor, todavia, a partir do princípio da recepção e interpretação que os leitores realizavam das obras que liam, motivações propícias a desconstruções e posicionamentos contestadores com relação à Religião, à religiosidade e à fé.

Dessa forma, a pergunta que nos cabe aqui é por que Eça de Queirós "nos coloca diante de situações moralmente nauseantes e terrivelmente grotescas, fazendo-nos compartilhar das perplexidades cobardes, dos remorsos apavorados de várias personagens burguesas ou aristocráticas" (SARAIVA; LOPES, 1989, p. 945) e Camilo Castelo Branco apresenta somente "uma grandeza trágica de paixões e situações, uma narração precisa e rápida das acções decisivas, caracteres psicológicos secundários inteiramente subordinados às necessidades de dignificação do conflito central" ". (SARAIVA; LOPES, 1989, p. 856)?

8 Cabe mencionar que Saraiva e Lopes pressupõem que há laivos de crítica social na obra camiliana, mas parecem propor que eles são mais aparentes quando Camilo se dedica à representação do meio popular. Tal pressuposição pode ser percebida na História da Literatura Portuguesa, logo depois dessa citação exposta aqui, utilizando inclusive personagens de Amor de perdição como exemplo. Há o endosso de que existem também caracteres "por vezes realistas e enérgicos, sobretudo quando extraídos do meio popular (João da Cruz e Mariana)". Porém, vale lembrar que os críticos sugerem que se há laivos de crítica social na obra camiliana, eles somente são aparentes quando Camilo se dedica à representação do meio popular, sugestão que esta minha análise espera problematizar. 
Ambas as proposições - e por que não dizer definições que se cristalizaram em torno de ambos os autores - são da História da Literatura Portuguesa, de António José Saraiva (1917-1993) e Óscar Lopes (19172013), e traduzem muito bem a visão ainda permanente sobre o fato de que, diferente dos Realistas, a crítica social presente na obra camiliana estaria subordinada ou somente atuando em função da concretização do conflito central dos romances românticos.

No início deste trabalho sugeri que as obras supostamente representantes da estética romântica em Portugal - e no caso de Amor de perdição, acrescidas com o epíteto de ultrarromânticas - possivelmente não foram consideradas como veiculadoras contumazes de crítica com intuito de transformação social, porque, segundo algumas leituras críticas, tal característica era flagrante e declaradamente pertencente aos projetos realistas. Porém, como pretendi demonstrar por intermédio da crítica anticlerical, uma leitura mais acurada da maneira com que a crítica social veiculada em obras românticas/ultrarromânticas é desenvolvida, poderia demonstrar o quanto é questionável a necessidade de fronteiras entre estéticas e de demarcações de quais autores e obras pertenceriam a tal ou qual período literário.

Aliás, poderíamos considerar de antemão, sem ter que recorrer à produção final de Camilo, o quanto são questionáveis as declarações do próprio escritor de que não fazia romances com fins de intervenção social. Tomemos como exemplo as irônicas afirmações feitas por Camilo no prefácio à quinta edição de Amor de Perdição, publicada em 1879, auge do Realismo. No texto nota-se a fina ironia camiliana questionando características realistas das quais seu romance teoricamente não estava prenhe, todavia, como espero ter demonstrado, algumas destas características podem ser claramente constatadas nos inúmeros trechos que citei neste trabalho, quando a crítica anticlerical era destilada no enredo da história:

Se comparo o Amor de Perdição, cuja 5.a edição me parece um êxito fenomenal e extralusitano, com o Crime do Padre Amaro e O Primo Basílio, confesso, voluntariamente resignado, que para o esplendor destes dois livros foi preciso que a Arte se ataviasse dos primores lavrados no transcurso de dezasseis anos. O Amor de Perdição, visto à luz elétrica do criticismo moderno, é um romance romântico, declamatório, com bastantes aleijões líricos, e umas idéias celeradas que chegam a tocar no desaforo do sentimentalismo. Eu não cessarei de dizer mal desta novela, que tem a boçal inocência de não devassar alcovas, a fim de que as senhoras a possam ler nas salas, em presença de suas filhas ou de suas mães, e não precisem de esconder-se com o livro no seu quarto de banho. [...] São Miguel de Seide, 8 de Fevereiro de 1879. CAMILO CASTELO BRANCO (AP, 1987, p. 16). 
Pode ser que para ler os inúmeros trechos de crítica social presentes em Amor de perdição, as mocinhas não precisassem ter a atitude extrema de se trancarem nos quartos de banho, mas, certamente, eram levadas a refletir acerca de diversas situações imorais, antiéticas e de ignominiosa hipocrisia que as cercavam. As senhoras leitoras, "as carinhosas amigas de todos os infelizes" (AP, 1987, p. 18), como Camilo as denomina, eram levadas, sem dúvidas, entre as lágrimas ocasionadas pelas agruras vivenciadas pelo triângulo amoroso Teresa - Simão - Mariana, a refletirem sobre as intempéries que dificultavam a concretização de um amor puro, inocente e avassalador, mas, para além disso, eram também levadas a indignarem-se contra os interesses escusos, jogos de poder e hipocrisias que regiam a sociedade que as cercavam.

\section{REFERÊNCIAS}

AMARAL, Emília; PATRocínIO, Mauro Ferreira do; LEITE, Ricardo Silva; BARBOSA, Severino Antônio Moreira. Novas Palavras. 1. ed. São Paulo: FTD, 2010. v. 2.

CASTELO BRANCO, Camilo. Amor de perdição. São Paulo: Click Editora, 1987.

FRANCHETTI, Paulo. A novela camiliana.

São Paulo: Ateliê Editorial, 2007. p. 87-100.

. Estudos de literatura portuguesa e brasileira.

QUEIRós, Eça de. O crime do padre Amaro. Porto: Lello e Irmãos, 1950. . A relíquia. Porto: Lello e Irmãos, 1976.

QUENTAL, Antero de. Causas da decadência dos povos peninsulares nos últimos três séculos. In: FIGUEIREDO, Fidelino (Org.). Prosas Escolhidas. Rio de Janeiro: Livros de Portugal, 1942. p. 95-142.

SARAIVA, António José; LOPES, Óscar. História da Literatura Portuguesa. 15. ed. Porto: Porto Editora, 1989.

SERRÃO, Joel. Portugueses Somos. Lisboa: Livros Horizontes, 19--.

Submetido em: 08/03/2013

Aceito em: 30/06/2013 